\title{
G scment \\ Consumption of ultra-processed foods is associated with abdominal obesity in rotating shift workers
}

Luiz Antônio Alves de Menezes Júnior ( $\square$ luiz.menezes@aluno.ufop.edu.br)

Federal University of Ouro Preto https://orcid.org/0000-0002-4497-5358

\section{Virgínia Capistrano Fajardo}

Federal University of Minas Gerais https://orcid.org/0000-0001-9175-6142

Jonathas Assis de Oliveira

Federal University of Ouro Preto

George Luiz Lins Machado-Coelho

Federal University of Ouro Preto https://orcid.org/0000-0002-9806-9721

\section{Fausto Aloísio Pedrosa Pimenta}

Federal University of Ouro Preto https://orcid.org/0000-0002-9169-0443

Fernando Luiz Pereira de Oliveira

Federal University of Ouro Preto https://orcid.org/0000-0001-6513-3339

\section{Raimundo Marques do Nascimento Neto}

Federal University of Ouro Preto

\section{Sílvia Nascimento de Freitas}

Federal University of Ouro Preto https://orcid.org/0000-0002-4119-0352

\section{Adriana Lúcia Meireles}

Federal University of Ouro Preto https://orcid.org/0000-0002-1447-953X

\section{Research Article}

Keywords: Minimally processed foods, Ultra-processed food, Shift work, Waist circumference, Nutritional food quality

Posted Date: November 15th, 2021

DOI: https://doi.org/10.21203/rs.3.rs-1074710/v1

License: (1) (1) This work is licensed under a Creative Commons Attribution 4.0 International License.

Read Full License 


\section{Abstract}

Background and aims: Higher intake of ultra-processed foods might be associated with an increased risk of obesity. Our objective was to evaluate the consumption of ultra-processed foods and their association with nutrient intake and excess body adiposity in shift workers.

Design: Cross-sectional study conducted in 2016 with 238 male rotating shift workers. Dietary data is obtained by the 24-hour recall and classified according to processing by the NOVA classification system. Body adiposity indicators assessed were waist circumference and body mass index. Logistic regression models were built and adjusted for sociodemographic, lifestyle, and dietary variables.

Results: Ultra-processed foods represented on average $22.3 \%$ of the total caloric value of the individuals' food consumption, with a maximum value of $66.9 \%$. Participants with the highest tercile of ultraprocessed foods consumed more carbohydrate (57\%), protein (35\%), total fat (96\%), saturated fat (79\%), cholesterol $(68 \%)$, and sodium $(44 \%)$ intake compared to the first tercile $(p<0.001)$. The most frequencies of ultra-processed foods consumed were bread (81.0\%), followed by cookies (45.9\%), sweetened beverages $(45.7 \%)$, processed meats $(46.8 \%)$, and margarine $(46.8 \%)$. In multivariable analysis, the highest consumption of ultra-processed foods had $183 \%$ higher odds of abdominal obesity $(\mathrm{OR}=2.83$, 95\% Cl 1.29-6.22), compared with the lowest consumption.

Conclusion: Ultra-processed foods are important contributors to the energy intake of these workers, and higher consumption of ultra-processed foods was associated with abdominal obesity.

\section{Introduction}

Ultra-processed foods (UPFs) are industrial formulations with ingredients containing few or no whole foods, which result from a series of industrial processes and the addition of additives to improve durability, accessibility, convenience, palatability, and readiness for consumption of the final product [1]. Household purchase of UPFs has increased in recent decades[2, 3]. In Brazil, the percentage of calories in this food group has increased by up to $40 \%$ since 1987, according to the Household Budget Survey (HBS) [4]. High consumption of UPFs is also observed in countries such as Canada and Sweden $[3,5]$.

The impact of high consumption of ultra-processed health foods is harmful to health, as most are high in sodium, saturated fat, trans fat, sugar, and high-energy density [6, 7]. Consumption of UPFs is associated with poor diet quality[8], and increased consumption of UPFs is associated with lower fiber intake, micronutrients, and phytochemicals[2, 9].

Household availability of UPFs has shown a positive association with the prevalence of obesity and overweight[10]. A meta-analysis study showed that higher consumption of ultra-processed food was associated with a greater risk of overweight and obesity, abdominal obesity in adults[11]. In addition, shift work is also considered one of the determinants of obesity. As shown by Peplonska, et al. (2015) that for every 1000 shifts worked days there is an increase in body mass index (BMI) by $0.477 \mathrm{~kg} / \mathrm{m}^{2}$ and a 1.09 
$\mathrm{cm}$ increase in waist circumference (WC)[12]. An important factor in gaining weight is circadian cycle dysregulation and increased artificial exposure at night, or the average timeframe that can lead to hormonal imbalances, sleep changes, and biological rhythm dysregulation[13].

Sleep dysregulation and meal changes due to shift work are responsible for modulating and controlling the patterns of human physiology such as secretion of leptin, ghrelin, glucose, insulin, fatty substances, triglycerides, and other substances[14]. Under normal conditions, these hormones act by regulating eating behavior, leptin is released during satiety-induced eating, and ghrelin is taken during the hunger-induced meal break[13]. However, in shift workers there are changes in mealtimes, promoting a dysregulation of these hormone secretion patterns, with a decrease in leptin levels and an attenuation of suppression of ghrelin after meals, contributing to increased appetite and weight gain[15]. In addition, another factor that may predispose to metabolic disorders is inadequate food choices. David et al. (2018) evaluated the appetite motivation for several ultra-processed products, which caused a high preference for these foods due to their palatability[16].

To our knowledge, this is the first study to evaluate the consumption of UPFs associated with body adiposity in these workers. Furthermore, according to the disorders caused by shift work, it is suggested that there may be a high consumption of UPFs by this population and, consequently, a higher probability of anthropometric changes. Given the above, the objective was to evaluate the consumption of UPFs and their association with nutrient intake and excess body adiposity in shift workers.

\section{Materials And Methods}

\section{Study Design and Population}

A cross-sectional study was conducted in 2016 with a rotating shift worker population of an iron ore extraction company in the region of Iron Quadrangle, Minas Gerais, Brazil. The workers were male offroad truck operators. The time for rotating shifts was $6 \mathrm{~h}$, followed by $12 \mathrm{~h}$ of rest, from $7 \mathrm{pm}$ to $1 \mathrm{am}, 1$ $\mathrm{pm}$ to $7 \mathrm{pm}, 7$ am to $1 \mathrm{pm}$, and $1 \mathrm{am}$ to $7 \mathrm{am}$. After completing the four-shift cycle, the workers had a day off.

The participants were previously evaluated in a study entitled "Metabolic syndrome in mining workers in the state of Minas Gerais, Brazil," a screening study conducted by the Federal University of Ouro Preto to identify the prevalence of cardiovascular risk factors in this population. For the study, the total population of shift workers ( $\mathrm{n}=952)$ was invited, and after exclusions due to refusals, vacations, absences, resignations or not completing the food recordatory, 238 individuals answered the questionnaire and had an anthropometric evaluation.

\section{Data collect}

Data collection was performed at the company's outpatient clinics by teams previously trained to apply, assess anthropometric and food survey data. The social, demographic, and economic variables 
evaluated were: sex, age, self-reported skin color, and education. Age was categorized as $<30$ years, $30-$ 39 years, and 40 years or more; the self-declared skin color was categorized as not white (black, brownskinned yellow or indigenous) and white; education was categorized up to high-school graduate, and technical or university education. The clinical evaluation was carried out employing a questionnaire about smoking, alcohol consumption, and physical activity. Smoking was classified as non-smokers, those who had never smoked or had quit smoking more than six months ago, and smokers, those who currently smoke or had quit smoking less than six months ago. Alcohol consumption was classified as yes or no. The instrument used to assess the level of physical activity was the International Physical Activity Questionnaire (IPAQ) version 8 - long form. The workers were classified as high physical activity $\geq$ 600 measure total energy - $\min /$ week [17].

In the collection of anthropometric data, weight was measured on the portable TANITA® model BC558 body composition monitor, with a maximum capacity of $150 \mathrm{~kg}$ and an accuracy of $0.1 \mathrm{~kg}$ (Tanita Corporation of America, Inc., Arlington Heights, Illinois, USA) and the height on the AlturExata ${ }^{\circledR}$ portable stadiometer with centimeter-scale and one-millimeter accuracy (AlturExata, Belo Horizonte, Minas Gerais, Brazil). In both procedures, the subjects were evaluated in an upright anatomical position with a fixed point in front, barefoot, and with the feet correctly positioned in the center of the platform according to the instruction manual. WC was measured in triplicate with a simple, inelastic tape measure at the midpoint between the iliac crest and the last costal $\operatorname{arch}[18]$. Values of $W C \geq 90.0 \mathrm{~cm}$ were classified as abdominal obesity[19]. BMI was calculated from the formula: weight $(\mathrm{kg}) /$ height $(\mathrm{m}) 2$, considered as excess weight values considered with $\mathrm{BMI} \geq 25.0 \mathrm{~kg} / \mathrm{m}^{2}$ [18].

The food survey was conducted through the 24-hour recall (R24h). For accuracy of dietary intake were asked the time and place of each meal, the type of food consumed, the method of preparation, the amount in portions, and if possible the brand of products. The book "Food Consumption: Viewing Portions" with illustrative photos of various portions of food was used to help individuals determine their intake[20]. Dietary data were converted to gram and milliliter to enable a chemical analysis of food intake and were later included in the Virtual Nutri Plus version 2.0 nutritional analysis program that provided total energy intake, macros, and micronutrients of the food. After the converted data, the energy density of the food was calculated by dividing the total calories (kcal) per gram (g) of food for further analysis.

\section{Food Classification}

All reported foods were classified according to the nature, extent, and purpose of food processing. Essentially, foods were divided into three main groups according to the NOVA food classification[21]. The first group includes unprocessed or minimally processed foods such as fresh vegetables and fruits, grains, roots, tubers, and others. The second group is processed foods such as canned or bottled vegetables and pickled vegetables; unprocessed processed meat and fish such as ham, bacon, smoked fish; cheese, and others. And the third group, is the ultra-processed products, such as chips, many kinds of sweets, fatty or salty snacks, ice cream, chocolates, hamburgers, bread, cookies, and others. More detailed information on the classification methodology can be found in another study. 
Furthermore, the consumption of UPFs was divided into terciles using the caloric value (kcal) of UPFs. Tercile 1 (T1) contained the lowest ultra-processed kcal values and tercile 3 (T3) the highest values.

\section{Statistical analysis}

Shapiro Wilk test was used to assess the normality of the data, and data were described as the median and interquartile range (IQR). Categorical variables were presented with frequency values absolute (n) and relative (\%). To compare the variables with the ultra-processed terciles, Pearson chi-squared or Kruskal-Wallis test and post-hoc Dunn Bonferroni were used.

Binary logistic regression models were used to assess the association between ultra-processed food consumption and excess weight or abdominal obesity. The first (lowest) tercile was considered as reference and odds ratios (OR) and their $95 \%$ confidence intervals $(\mathrm{Cl})$ were obtained. We built two logistic regression models with consecutive adjustment levels: model 1 was adjusted for sociodemographic variables (age and education); model 2 was additionally adjusted for lifestyles and dietary variables (physical activity, and total dietary energy). Furthermore, linear trends across quartiles were tested by modeling the median value of each quartile as an ordinal variable.

Sampling power (a posteriori) was performed using the OpenEpi program version 3.1.9.2, and data on the proportion and sample size of similar studies. This was performed for the whole sample, with an estimated power of 0.99 . For all tests, a significance level of $5 \%$ was adopted. The analyses were performed with STATA software version 15.0 for Windows (StataCorp LP, College Station, TX, USA).

\section{Ethical statement}

This study was conducted according to the guidelines laid down in the Declaration of Helsinki and all procedures involving human subjects were approved by the Research Ethics Committee of the Federal University of Ouro Preto (CAAE: 39682014.7.0000.5150). Written informed consent was obtained from all subjects. This study followed reported guidelines dictated by the Strengthening the Reporting of Observational Studies in Epidemiology (STROBE).

\section{Results}

The total sample consisted of 238 workers aged 26 to 60 years, with a median age of 38 years (IQR: 9.0). Consumption of UPFs contributed with a mean of $22.3 \%( \pm 15.2)$ of the individuals' total calorie diet, with a minimum value of 0 for those who did not consume UPFs and a maximum value of $66.9 \%$. Those who did not consume any UPFs were $0.06 \%$ of the sample studied. Approximately two in three workers were overweight $\left(\mathrm{BMI} \geq 25.0 \mathrm{~kg} / \mathrm{m}^{2}\right)$ or abdominal obesity $(\mathrm{WC} \geq 90 \mathrm{~cm})($ Table 1$)$.

\section{$\underline{\text { Table } 1}$}

The most frequencies of UPFs consumed were bread (81.0\%), followed by cookies (45.9\%), sweetened beverages $(45.7 \%)$, processed meats $(46.8 \%)$, and margarine $(46.8 \%)$. Of these, the highest caloric 
contribution in the total daily energy value (\% of energy) was from ultra-processed bread $10.9 \%$ of energy), cookies (5.2\% of energy), and sweetened beverages (3.7\% of energy) (Table 2 ).

\section{$\underline{\text { Table } 2}$}

Macronutrient intake of participants was assessed according to terciles of ultra-processed food intake (Table 3). There was a significant increase in carbohydrate $(57.0 \%)$, protein $(35.0 \%)$, total fat $(96.0 \%)$, saturated fat (79.0\%), cholesterol (68.0\%) and sodium (44.0\%) intake between 1st tercile and 3rd tercile ( $p$ $<0.001$ ) (Table 3). The consumption of UPFs ranged from $7.8 \%$ ( 1 st tercile) to $34.8 \%$ (3rd tercile) of total energy intake.

\section{$\underline{\text { Table } 3}$}

Crude and adjusted analyses of the association between the dietary contribution of UPFs and adiposity are shown in Table 4. No association was observed for excess weight, that is, excess weight was similar across terciles. For abdominal obesity, the univariate analysis showed the highest consumption of UPFs had $108 \%$ higher odds of abdominal obesity (OR=2.08; $95 \% \mathrm{Cl}$ : $1.01-4.28)$, compared with the lowest consumption. In multivariable analysis, after adjustments for sociodemographic, lifestyles, and dietary variables (model 2), the magnitude of the association increased and remained significant for 2 nd tercile $(\mathrm{OR}=2.27 ; 95 \% \mathrm{Cl}: 1.02-5.05)$ and 3rd tercile $(\mathrm{OR}=2.58 ; 95 \% \mathrm{Cl}: 1.22-5.48)($ Table 4$)$.

\section{$\underline{\text { Table } 4}$}

\section{Discussion}

This is the first study of male rotating shift workers in an iron ore mining company - to examine the consumption of UPFs and their association with body fat. We found that consumption of UPFs contributed about $22.3 \%$ of caloric intake and that workers with higher consumption of UPFs were more likely to have abdominal obesity.

The consumption of UPFs by rotating shift workers of the present study was $13.2 \%$ higher than that found in the Brazil Household Budget Survey (HBS) in 2018 (19.7\%) [22]. Besides, the HBS survey is conducted in large urban centers, which have a higher supply of UPFs compared to country towns[23]. The Pan American Health Organization (PAHO/WHO) has shown that there was a $48.0 \%$ increase in sales of UPFs and beverages in Latin America between 2000-2013, and in Brazil, this growth reached 29.7\% [24]. The present study also observed a high consumption of UPFs, suggesting that the consumption of UPFs by shift workers living in the country towns may be similar to that of large urban centers. Long term, the harmful effects of ultra-processed food consumption impact populations outside large urban centers.

To our knowledge, there are no studies in the literature that have evaluated the consumption of UPFs, with the NOVA methodology, in shift workers. However, a not peer-reviewed study published in the preprint medRxiv evaluated the processing classification of food intake of nurses, from the Nurses' Health Studies 
(NHS), a majority population of women highly exposed to work in rotating shifts[25]. In this study, the authors did not present the percentage of calorie intake coming from UPFs, but from a list of 205 foods consumed by these workers, $36.1 \%$ were identified as ultra-processed[25]. Besides, shift workers are more likely to have changes in eating patterns by omitting meals and consuming more foods at nonconventional times, especially quick-to-prepare foods, such as ultra-processed, since they are easy to consume[26].

The most frequently consumed UPFs among rotating shift workers included ultra-processed bread, crackers, sugary drinks, ultra-processed meats, and margarine. These results are similar to that found by Simões et al. (2018), to evaluate the contribution of UPFs to total calorie intake using baseline data from the Longitudinal Study of Adult Health-Brazil (ELSA-Brazil 2008-2010) in actives and retired civil servants aged 35-74 years from six higher education institutions of Brazil. A total of 14378 participants were evaluated, and among the UPFs, the most consumed were ultra-processed bread (3.8\%), sweets and treats (3.1\%), cakes and sweet biscuits (2.7\%), soft drinks, processed juice, and artificial juice (2.3\%) [27]. However, when we evaluated the percentage of caloric contribution of these foods, we observed that shift workers in our study have a higher caloric contribution of ultra-processed bread $(+7.1 \%)$, cookies, and bakery products $(+5.1 \%)$ when compared to ELSA-Brazil[27]. The percentage of calorie contribution from processed meats, yogurt, sausage meat, and sweetened beverages was similar to our study[27].

Obesity is a multifactorial disorder, with individual, sociocultural, and environmental contributors[18]. Among the determinants of obesity, high consumption of UPFs has been associated with greater chances of increased body adiposity[5].

In this study, we observed that more than $70 \%$ of the shift workers evaluated were overweight or had abdominal obesity. Furthermore, when evaluated for consumption of UPFs, workers in the highest tercile of consumption (3rd tercile) were more likely to have abdominal obesity, even controlling for sociodemographic, lifestyle, and dietary variables. These results are corroborated by other studies, as demonstrated by Canhada et al. (2020) in the ELSA-Brazil longitudinal study, where 11827 individuals were evaluated. The authors found that the highest quartile of ultra-processed food intake had a 27 and $33 \%$ increased risk of weight and waist circumference increase $(\mathrm{RR}=1.27 ; 95 \% \mathrm{Cl}: 1.07-1.50$ and $\mathrm{RR}=1.33$; $95 \%$ Cl: $1.12-1.58$, respectively). Besides, approximately $15.0 \%$ of cases of overweight and abdominal obesity could be attributed to consumption higher than $17.8 \%$ of energy from UPFs[28]. Moradi et al. (2021) found similar results in a meta-analysis of observational studies. Evaluating 12 studies, they found that consumption of UPFs was associated with a $36.0 \%$ greater chance of overweight (OR=1.36; $95 \% \mathrm{Cl}: 1.14,1.63 ; \mathrm{I}=73 \%)$, and $41 \%$ greater chance of abdominal obesity (OR=1.41; $95 \% \mathrm{Cl}: 1.18,1.68$; $12=62 \%$ ). In rotating shift workers, there are no results in the literature on the consumption of UPFs, however, an analysis of three American cohorts of nursing professionals, who usually work rotating shifts, showed that consumption of foods such as sweets, processed meats, french fries, and sugary drinks was strongly associated with weight gain in American adults[29]. However, the relationship between the consumption of foods aggregated according to their degree of processing (i.e., UPFs) and overweight has not yet been examined. 
Analyzes of the Brazilian food consumption survey conducted in 2008-2009 showed that the ultraprocessed food set has 2.5 times more energy per gram than the fresh, minimally processed food set and culinary preparations based on these foods[9]. Therefore, although most studies do not evaluate the relationship between ultra-processed consumption and indicators of adiposity, studies show in shift workers a significant increased risk of overweight (RR: 1.25; 95\% Cl: $1.08-1.44$ ), obesity (RR: 1.17; 95\% Cl: $1.12-1.22)[33]$ and abdominal obesity $(\mathrm{OR}=1.10 ; 95 \% \mathrm{Cl}=1.01-1.20)[34]$. Moreover, these workers have increased consumption of foods rich in simple carbohydrates, fat, and other inadequate components due to working hours[30], which together may negatively impact the health of these workers. This may be related to increased satiety or decreased food intake after fiber intake, with stomach distension, fermentation, and changes in intestinal hormones as possible appetite control mechanisms[31]. Higher fiber and whole-grain intake are associated with lower BMI and weight gain prevention compared to low fiber and whole-grain diets[32].

Our study also found an important result, that a significant increase in the intake of carbohydrates, protein, total fat, saturated fat, cholesterol, and sodium were found when comparing the terciles of ultraprocessed food consumption. No significant relationship was found with fiber consumption but noted that the fibers are below the recommended[33] in all terciles. Bielemann et al. (2015) in a cohort study found a significant relationship between increased intake of UPFs with lower dietary fiber intake and higher sodium intake[34]. Louzada, et al. (2015) demonstrated that increased consumption of UPFs was associated with increased saturated fat, trans fat, and free sugar, and inversely associated with fiber and protein content[35]. The authors also noted that only the $20 \%$ of Brazilians who least consume these foods had a diet that meets or approaches World Health Organization (WHO) recommendations for the prevention of NCDs, like cardiovascular diseases, cancers, chronic respiratory diseases, and diabetes [35].

Among the study's limitations are possible inherent biases in food-related questionnaires, such as memory errors, underreporting, and conscious or subconscious modification of food consumption patterns. To minimize these biases, the data collection team received training, a manual for consultation, and the instruments used were pre-tested. Another possible limitation of our study was the evaluation of food intake by a single 24-hour food recall; due to the logistics of the workers, it was not possible to evaluate on more than one day, which may not represent the food intake of atypical days. However, it should be noted that most of the food consumed by the workers, especially the UPFs, was offered by the employer, and thus we believe that there were no very significant changes in the consumption of UPFs by these workers.

Our study has strengths, we are the first to evaluate the consumption of UPFs and the association with abdominal obesity in rotating shift workers. The evaluation of food intake by the NOVA system in these workers is of key relevance and is by the dietary guidelines for the Brazilian population.

The results of our study, suggest that UPFs are important contributors to the energy intake of these workers, and were associated with poor nutritional quality. Besides, increased consumption of UPFs is 
associated with a greater chance of abdominal obesity. This population of workers already has significant metabolic and sleep dysfunction, as demonstrated by previous studies [36-38]. Strategies to reduce the consumption of this food group, such as maintaining a traditional food culture and enhancing a diet based on fruits, vegetables, and legumes, should be encouraged as preventive approaches for obesity. However, further studies with this population of workers are needed to confirm our findings

\section{Declarations}

\section{Acknowledgments}

This study was supported by the Brazilian Council for Scientific and Technological Development (CNPq, Distrito Federal, Brazil) and Coordination for the Improvement of Higher Education Personnel-Brazil (CAPES), finance code 001 for Ph.D. student scholarship, and provided financial support for the conduct of the research. Moreover, we would acknowledge the Federal University of Ouro Preto (UFOP) and the Research and Education Group in Nutrition and Collective Health (GPENSC).

\section{Statement of Authorship}

All authors made significant contributions in conducting the study.

\section{Conflicts of interest}

The authors declare that they have no conflicts of interest related to this article. RMNN, SNF, GLLMC, FAPP, FLPO contributed to the conception and design of the work, to the acquisition, analysis, and interpretation of data, and final approval of the version to be submitted. LAAMJ, VCF, JAO contributed to the acquisition, analysis, and interpretation of data, and carried out the drafting of the work, and final approval of the version to be submitted. ALM contributed to the analysis and interpretation of data, carried out the drafting of the work, and critical review of intellectual content.

\section{Tables}


Table 1: Characteristics of rotating shift workers in the Iron Quadrangle, Brazil, 2016 Total $(n=238)$

Food processing ${ }^{\mathrm{a}}$

Unprocessed or minimally processed foods

$1151.8(57.9 \%)$

Processed foods

Ultra-processed foods

Age, n (\%)

$<30$ years

$375.0(18.9 \%)$

$459.1(22.3 \%)$

30-39 years

$12(5.26)$

$127(55.7)$

40-60 years

$89(39.1)$

Ethnicity, n (\%)

White

$68(28.8)$

Not-white

$168(71.2)$

Marital status, n (\%)

$191(80.9)$

Not Married

Education, n (\%)

High-school graduate

$134(56.8)$

Technical or university education

$102(43.2)$

Tobacco consumption, n (\%)

Smokers

$163(71.2)$

Non-smoker

66 (28.8)

Alcohol consumption, n (\%)

Yes

$153(64.8)$

No

Physical activity ${ }^{\mathrm{b}}, \mathrm{n}(\%)$

High

$70(29.7)$

Low/moderate

$166(70.3)$

Nutritional status, n (\%)

Excess weight $(\mathrm{BMI} \geq 25.0 \mathrm{~kg} / \mathrm{m} \square)$

$170(72.0)$

Abdominal obesity (WC $\geq 90.0 \mathrm{~cm}$ )

$169(71.9)$

Data are shown as mean (standard deviation), median (IQR), or absolute and relative frequency. BMI: Body mass index; WC: Waist circumference

${ }^{\mathrm{a}}$ Food processing is demonstrated by kcal/day and percentage of calorie contribution

b Physical Activity evaluated by IPAQ. 
Table 2- Characterization of the ultra-processed food consumed by rotating shift workers in the Iron Quadrangle, Brazil, 2016

\begin{tabular}{|c|c|c|c|}
\hline Foods & $\begin{array}{l}\text { Percentage of workers } \\
\text { that consume (\%) }\end{array}$ & $\begin{array}{c}\text { Caloric } \\
\text { contribution } \\
\text { (kcal/day) }\end{array}$ & $\begin{array}{l}\text { Percentage (\%) of total } \\
\text { energy intake (kcal/day) }\end{array}$ \\
\hline Breads $^{1}$ & 81.0 & 243.4 & 10.9 \\
\hline Cookies & 45.9 & 251.3 & 5.2 \\
\hline $\begin{array}{l}\text { Cake and } \\
\text { bakery } \\
\text { products }\end{array}$ & 21.6 & 299.5 & 2.7 \\
\hline $\begin{array}{l}\text { Sweetened } \\
\text { beverages }^{2}\end{array}$ & 45.7 & 157.6 & 3.7 \\
\hline $\begin{array}{l}\text { Processed } \\
\text { meat }^{3}\end{array}$ & 46.8 & 89.0 & 2.1 \\
\hline Margarine & 46.8 & 131.5 & 1.7 \\
\hline Dairy drinks & 13.4 & 203.4 & 1.5 \\
\hline $\begin{array}{l}\text { Processed } \\
\text { cheese }\end{array}$ & 7.6 & 116.2 & 0.4 \\
\hline Ready sauces ${ }^{4}$ & 6.7 & 172.9 & 0.6 \\
\hline $\begin{array}{l}\text { Canned } \\
\text { vegetables }\end{array}$ & 3.1 & 51.6 & 0.1 \\
\hline $\begin{array}{l}{ }^{1} \text { Including light b } \\
{ }^{2} \text { Including sausag } \\
3 \text { Including soft dr }\end{array}$ & $\begin{array}{l}\text { white/pita bread, sweet/hom } \\
\text { orizo/Vienna sausage, hambu } \\
\text { processed juice and artificial }\end{array}$ & $\begin{array}{l}\text { le bread, whole g } \\
\text { (beef), ham/morta }\end{array}$ & $\begin{array}{l}\text { bread, Brazilian cheese bread } \\
\text { alami. }\end{array}$ \\
\hline
\end{tabular}


Table 3: Consumption of nutrient intake according to the terciles of ultra-processed food consumption by rotating shift workers in the Iron Quadrangle, Brazil, 2016.

\section{Terciles of ultra-processed food} consumption (kcal/day)

\begin{tabular}{|c|c|c|c|c|c|}
\hline & Total & $1^{\text {st }}$ Tercile & $2^{\text {nd }}$ Tercile & $3^{\text {th }}$ Tercile & $p$ \\
\hline $\begin{array}{l}\text { Ultra-processed foods } \\
\text { (kcal/day) }\end{array}$ & $\begin{array}{c}365.6 \\
(486.1)\end{array}$ & $\leq 233.9$ & $240.0-566.6$ & $\begin{array}{l}566.7- \\
2142.1\end{array}$ & - \\
\hline $\begin{array}{l}\text { Ultra-processed (\% of } \\
\text { energy) }\end{array}$ & $22.3(15.2)$ & $7.8(10.6)^{\mathrm{a}}$ & $19.7(10.9)^{b}$ & $34.8(15.9)^{\mathrm{C}}$ & $\begin{array}{l}\leq \\
0.001\end{array}$ \\
\hline $\begin{array}{l}\text { Total energy intake } \\
\text { (kcal) }\end{array}$ & $\begin{array}{l}1852.0 \\
(906.9)\end{array}$ & $\begin{array}{l}1515.0 \\
(801.6)^{\mathrm{a}}\end{array}$ & $\begin{array}{c}1767.7 \\
(691.6)^{b}\end{array}$ & $\begin{array}{l}2406.5 \\
(892.1)^{\mathrm{c}}\end{array}$ & $\begin{array}{l}\leq \\
0.001\end{array}$ \\
\hline Energy density (kcal/g) & $1.2(0.3)$ & $1.1(0.3)^{\mathrm{a}}$ & $1.2(0.2)^{b}$ & $1.3(0.3)^{\mathrm{C}}$ & $\begin{array}{l}\leq \\
0,001\end{array}$ \\
\hline Carbohydrate (g) & $\begin{array}{c}240.7 \\
(137.8)\end{array}$ & $\begin{array}{c}198.8 \\
(109.9)^{\mathrm{a}}\end{array}$ & $\begin{array}{c}229.1 \\
(112.3)^{b}\end{array}$ & $\begin{array}{c}312.5 \\
(124.1)^{\mathrm{C}}\end{array}$ & $\stackrel{\leq}{0.001}$ \\
\hline Protein $(g)$ & $78.7(45.0)$ & $70.5(41.1)^{\mathrm{a}}$ & $78.5(38.9)^{b}$ & $95.2(54.5)^{\mathrm{C}}$ & $\stackrel{\leq}{0.001}$ \\
\hline Total fat (g) & $60.1(45.7)$ & $44.0(32.6)^{\mathrm{a}}$ & $57.1(27.2)^{b}$ & $86.4(44.8)^{\mathrm{C}}$ & $\begin{array}{l}\leq \\
0.001\end{array}$ \\
\hline Saturated fat (g) & $13.1(12.3)$ & $10.2(10.2)^{\mathrm{a}}$ & $12.8(9.7)^{\mathrm{b}}$ & $18.3(17.4)^{\mathrm{C}}$ & $\stackrel{\leq}{0.001}$ \\
\hline Total fibers $(\mathrm{g})$ & $17.1(10.9)$ & $16.4(10.7)^{\mathrm{a}}$ & $16.5(10.4)^{\mathrm{a}}$ & $17.6(11.2)^{\mathrm{a}}$ & 0.433 \\
\hline Cholesterol (mg) & $\begin{array}{c}176.6 \\
(188.2)\end{array}$ & $\begin{array}{c}151.3 \\
(118.6)^{\mathrm{a}}\end{array}$ & $\begin{array}{c}176.1 \\
(171.7)^{\mathrm{a}}\end{array}$ & $\begin{array}{c}255.1 \\
(227.8)^{\mathrm{b}}\end{array}$ & $\begin{array}{l}\leq \\
0.001\end{array}$ \\
\hline Sodium (mg) & $\begin{array}{l}2350.4 \\
(1359.7)\end{array}$ & $\begin{array}{c}1934.2 \\
(1052.0)^{\mathrm{a}} \\
\end{array}$ & $\begin{array}{c}2250.8 \\
(1333.3)^{b}\end{array}$ & $\begin{array}{c}2789.1 \\
(1848.4)^{\mathrm{C}}\end{array}$ & $\begin{array}{c}\leq \\
0.001\end{array}$ \\
\hline
\end{tabular}

Data are shown as median and interquartile range (IQR). Kruskal Wallis and post-hoc Dunn Bonferroni was performed to compare the medians. 
Table 4: Association of excess body adiposity according to the terciles of ultra-processed food consumption by rotating shift workers in the Iron Quadrangle, Brazil, 2016

$$
\text { Terciles of ultra-processed food consumption (kcal/day) }
$$

\begin{tabular}{lcccc} 
Body adiposity & $1^{\text {st }}$ Tercile & $2^{\text {nd }}$ Tercile & $3^{\text {th }}$ Tercile & \\
\hline $\begin{array}{l}\text { Excess weight } \\
\text { (BMI } \geq 25.0 \mathrm{~kg} / \mathrm{m} \square)\end{array}$ & Reference & OR (95\% CI) & OR (95\% CI) & p for trend \\
Univariate & 1.00 & $1.18(0.59-2.37)$ & $1.20(0.60-2.41)$ & 0.597 \\
Model 1 & 1.00 & $1.30(0.64-2.64)$ & $1.31(0.65-2.66)$ & 0.445 \\
Model 2 & 1.00 & $1.47(0.71-3.02)$ & $2.00(0.89-4.50)$ & 0.296
\end{tabular}

\begin{tabular}{|c|c|c|c|c|}
\hline $\begin{array}{l}\text { Abdominal obesity } \\
(\mathrm{WC} \geq 90.0 \mathrm{~cm})\end{array}$ & Reference & OR (95\% CI) & OR (95\% CI) & $\mathrm{p}$ for trend $\mathrm{a}^{\mathrm{a}}$ \\
\hline Univariate & 1.00 & $1.26(0.64-2.48)$ & $2.08(1.01-4.28) *$ & 0.045 \\
\hline Model 1 & 1.00 & $1.31(0.65-2.62)$ & $2.37(1.12-5.01)^{*}$ & 0.023 \\
\hline Model 2 & 1.00 & $2.27(1.02-5.05) *$ & $2.58(1.22-5.48) * *$ & 0.013 \\
\hline
\end{tabular}

OR: Odds ratio; 95\% CI: confidence interval of 95\%; BMI: body mass index. WC: waist circumference.

a Based on consumption of ultra-processed food as a continuous variable.

Model 1: adjusted for age, education and ethnicity; Model 2 adjusted as in model 1 plus physical activity, alcohol and tobacco consumption; Model 3: adjusted as in model 2 plus total dietary energy and dietary energy from minimally processed food.

$*$ p-value $\leq 0,05 ; * *$-value $\leq 0,01$

\section{References}

1. Monteiro CA, Cannon G, Levy RB, Moubarac J-C, Louzada ML, Rauber F, et al. Ultra-processed foods: what they are and how to identify them. Public Health Nutr 2019;22:936-41. https://doi.org/10.1017/S1368980018003762.

2. Martins APB, Levy RB, Claro RM, Moubarac JC, Monteiro CA. Increased contribution of ultraprocessed food products in the Brazilian diet (1987-2009). Rev Saude Publica 2013;47. https://doi.org/10.1590/S0034-8910.2013047004968.

3. Moubarac JC, Batal M, Martins APB, Claro R, Levy RB, Cannon G, et al. Processed and ultraprocessed food products: Consumption trends in Canada from 1938 to 2011. Can J Diet Pract Res 2014;75:15-21. https://doi.org/10.3148/75.1.2014.15.

4. Monteiro CA, Moubarac JC, Cannon G, Ng SW, Popkin B. Ultra-processed products are becoming dominant in the global food system. Obes Rev 2013;14:21-8. https://doi.org/10.1111/obr.12107.

5. Juul F, Hemmingsson E. Trends in consumption of ultra-processed foods and obesity in Sweden between 1960 and 2010. Public Health Nutr 2015;18:3096-107. https://doi.org/10.1017/S1368980015000506. 
6. Poti JM, Mendez MA, Ng SW, Popkin BM. Is the degree of food processing and convenience linked with the nutritional quality of foods purchased by US households? Am J Clin Nutr 2015;101:125162. https://doi.org/10.3945/ajcn.114.100925.

7. Monteiro CA, Cannon G, Moubarac J-C, Levy RB, Louzada MLC, Jaime PC. The UN Decade of Nutrition, the NOVA food classification and the trouble with ultra-processing. Public Health Nutr 2018;21:5-17. https://doi.org/10.1017/S1368980017000234.

8. Louzada ML da C, Ricardo CZ, Steele EM, Levy RB, Cannon G, Monteiro CA. The share of ultraprocessed foods determines the overall nutritional quality of diets in Brazil. Public Health Nutr 2018;21:94-102. https://doi.org/10.1017/S1368980017001434.

9. Louzada ML da C, Martins APB, Canella DS, Baraldi LG, Levy RB, Claro RM, et al. Ultra-processed foods and the nutritional dietary profile in Brazil. Rev Saude Publica 2015;49:38-49. https://doi.org/10.1590/S0034-8910.2015049006132.

10. Canella DS, Levy RB, Martins APB, Claro RM, Moubarac J-C, Baraldi LG, et al. Ultra-Processed Food Products and Obesity in Brazilian Households (2008-2009). PLoS One 2014;9:e92752. https://doi.org/10.1371/journal.pone.0092752.

11. MM L, JA D, S B, C G-D, A L, A O, et al. Ultraprocessed food and chronic noncommunicable diseases: A systematic review and meta-analysis of 43 observational studies. Obes Rev 2021;22. https://doi.org/10.1111/OBR.13146.

12. Peplonska B, Bukowska A, Sobala W. Association of Rotating Night Shift Work with BMI and Abdominal Obesity among Nurses and Midwives. PLoS One 2015;10. https://doi.org/10.1371/JOURNAL.PONE.0133761.

13. Ulhôa MA, Marqueze EC, Burgos LGA, Moreno CRC. Shift Work and Endocrine Disorders. Int J Endocrinol 2015;2015:1-11. https://doi.org/10.1155/2015/826249.

14. Depner CM, Stothard ER, Wright KP. Metabolic consequences of sleep and circadian disorders. Curr Diab Rep 2014;14. https://doi.org/10.1007/s11892-014-0507-z.

15. Crispim CA, Waterhouse J, Dâmaso AR, Zimberg IZ, Padilha HG, Oyama LM, et al. Hormonal appetite control is altered by shift work: A preliminary study. Metabolism 2011;60:1726-35. https://doi.org/10.1016/j.metabol.2011.04.014.

16. David IA, Krutman L, Fernández-Santaella MC, Andrade JR, Andrade EB, Oliveira L, et al. Appetitive drives for ultra-processed food products and the ability of text warnings to counteract consumption predispositions. Public Health Nutr 2018;21:543-57. https://doi.org/10.1017/S1368980017003263.

17. IPAQ RC. Guideline for Data Processing and Analysis of the International Physical Activity Questionnaire (IPAQ): short and long forms 2005:1-15.

18. WHO WHO. Obesity: preventing and managing the global epidemic : report of a WHO consultation. Geneva: World Health Organization; 2000.

19. Alberti KGMM, Zimmet P, Shaw J. Metabolic syndrome-a new world-wide definition. A Consensus Statement from the International Diabetes Federation. Diabet Med 2006;23:469-80. https://doi.org/10.1111/j.1464-5491.2006.01858.x. 
20. Monteiro JP, Pfrimer K, Tremeschin MH, Molina M de C, Chiarello P, Vannucchi H. Consumo alimentar visualizando porções. 1st ed. Guanabara Koogan; 2007.

21. Monteiro CA, Levy RB, Claro RM, de Castro IRR, Cannon G. Uma nova classificação de alimentos baseada na extensão e propósito do seu processamento. Cad Saude Publica 2010;26:2039-49. https://doi.org/10.1590/S0102-311X2010001100005.

22. IBGE C de T e R. Pesquisa de Orçamentos Familiares 2017-2018: Análise de consumo alimentar pessoal no Brasil. Rio de Janeiro: 2020.

23. Reardon T, Timmer CP. The Economics of the Food System Revolution. Annu Rev Resour Econ 2012;4:225-64. https://doi.org/10.1146/annurev.resource.050708.144147.

24. Salud OP de la. Alimentos y bebidas ultraprocesados en América Latina: tendencias, efecto sobre la obesidad e implicaciones para las políticas públicas. OPS; 2015.

25. Khandpur N, Rossato S, Drouin-Chartier J-P, Du M, Martinez E, Sampson L, et al. Categorizing ultraprocessed food intake in large-scale cohort studies: evidence from the Nurses' Health Studies, the Health Professionals Follow-up Study, and the Growing Up Today Study. MedRxiv 2021:2021.02.08.21251384. https://doi.org/10.1101/2021.02.08.21251384.

26. Souza RV, Sarmento RA, de Almeida JC, Canuto R. The effect of shift work on eating habits: a systematic review. Scand J Work Environ Health 2019;45:7-21. https://doi.org/10.5271/sjweh.3759.

27. Simões B dos S, Barreto SM, Molina M del CB, Luft VC, Duncan BB, Schmidt MI, et al. Consumption of ultra-processed foods and socioeconomic position: a cross-sectional analysis of the Brazilian Longitudinal Study of Adult Health. Cad Saude Publica 2018;34:e00019717. https://doi.org/10.1590/0102-311X00019717.

28. Canhada SL, Luft VC, Giatti L, Duncan BB, Chor D, Fonseca M de JM da, et al. Ultra-processed foods, incident overweight and obesity, and longitudinal changes in weight and waist circumference: the Brazilian Longitudinal Study of Adult Health (ELSA-Brasil). Public Health Nutr 2020;23:1076-86. https://doi.org/10.1017/S1368980019002854.

29. Mozaffarian D, Hao T, Rimm EB, Willett WC, Hu FB. Changes in Diet and Lifestyle and Long-Term Weight Gain in Women and Men. Http://DxDoiOrg/101056/NEJMoa1014296 2011;364:2392-404. https://doi.org/10.1056/NEJMOA1014296.

30. Gupta CC, Coates AM, Dorrian J, Banks S. The factors influencing the eating behaviour of shiftworkers: What, when, where and why. Ind Health 2019;57:419-53. https://doi.org/10.2486/indhealth.2018-0147.

31. Clark MJ, Slavin JL. The effect of fiber on satiety and food intake: A systematic review. J Am Coll Nutr 2013;32:200-11. https://doi.org/10.1080/07315724.2013.791194.

32. Du H, Van Der A DL, Boshuizen HC, Forouhi NG, Wareham NJ, Halkjær J, et al. Dietary fiber and subsequent changes in body weight and waist circumference in European men and women. Am J Clin Nutr 2010;91:329-36. https://doi.org/10.3945/ajcn.2009.28191.

33. Brasil M da S. Guia alimentar para a população brasileira Promovendo a Alimentação Saudável. 2008. https://doi.org/978-85-334-2176-9. 
34. Bielemann RM. Consumption of ultra-processed foods and their impact on the diet of young adults. Rev Saúde Pública 2015:28-49. https://doi.org/10.1590/S0034-8910.2015049005572.

35. Louzada ML da C, Martins APB, Canella DS, Baraldi LG, Levy RB, Claro RM, et al. Impacto de alimentos ultraprocessados sobre o teor de micronutrientes da dieta no Brasil. Rev Saúde Pública 2015:45-9. https://doi.org/10.1590/S0034-8910.2015049006211.

36. Fajardo VC, Carvalho SR de, Diniz AP, Junior LAA de M, Neto RM do N, Freitas SN de. Concordância entre cintura hipertrigliceridêmica e cintura estatura hipertrigliceridêmica em trabalhadores em turnos alternantes. Demetra 2020. https://doi.org/10.12957.

37. Menezes Júnior LAA, Fajardo VC, do Nascimento Neto RM, de Freitas SN, de Oliveira FLP, Pimenta FAP, et al. Diagnostic accuracy of the Berlin questionnaire and the NoSAS score in detecting risk for obstructive sleep apnea in rotating shift workers. Sleep Breath 2021. https://doi.org/10.1007/s11325-021-02446-5.

38. Menezes-Júnior LAA de, Fajardo VC, Freitas SN de, Pimenta FAP, Oliveira FLP de, Machado-Coelho GLL, et al. Hypovitaminosis $D$ is associated with sleep disorders in workers on alternating shifts with cardiovascular risk factors. MedRxiv 2021:2021.05.04.21256625. https://doi.org/10.1101/2021.05.04.21256625. 